\title{
THE IMPACT OF CULTURAL EXPERIENCES OF TWO TRANSLATORS ON LITERARY TRANSLATION ${ }^{1}$
}

\author{
CHRISTIAN JAKOB ALTMANN \\ University of Silesia, Poland \\ kuba.alt@interia.pl
}

\begin{abstract}
The main focus of this paper is to examine the translation strategies of the translators of Herta Müller's novel Atemschaukel, Radka Denemarková (Czech) and Katarzyna Leszczyńska (Polish). The aim is to find out to what extent the cultural experience of these translators, consisting of biographical, artistic and linguistic aspects, has influenced the translations. Important in this context is the transculturalism of the author Herta Müller. She uses idiomatic expressions and uses borrowings and a multitude of neologisms, the translation of which is influenced to varying degrees by the cultural experience of the translators in their search for equivalence at the level of expression.
\end{abstract}

Key words: cultural experience, translators, transculturalism

\section{Introduction}

This article will deal with two outstanding translators of Herta Müller's prose, Radka Denemarková (Czech) and Katarzyna Leszczyńska (Polish).

The main focus is on the translation strategies of both translators with regard to "local" and "global" solutions, i.e. at the micro- and macro-levels. The illustrative material for this is Herta Müller's novel Atemschaukel (in English published under the title The Hunger Angel, translated by Julia Sherwood) and its translations into Czech (Rozhoupaný dech) and Polish (Huśtawka oddechu). The aim is to find out to what extent the cultural experience of the translators has influenced the translations. Important in this context is the transculturalism of the author Herta Müller. As a member of the German minority in Romanian Banat, her work mixes the culture of her mother tongue (German) with the regional culture of her childhood (Banat Swabian) and the majority culture (Romanian).

\footnotetext{
1 This work was supported by the National Science Centre, Poland, under research project "Translation in the (German-Polish-Czech) linguistic triangle on the example of the translations of Herta Müller's prose”, no. UMO-2018/29/N/HS2/02219.
} 
She uses idioms, borrowings and a variety of neologisms, which often have the structure of compound words. The cultural experience of the translators thus influences to varying degrees the equivalence they are looking for at the level of expression.

\section{The translator's skills as a mediator between cultures}

The author Herta Müller herself has probably best summed up the skills of a literary translator according to today's understanding:

You have to make the sound of the original sound again. The art of translation is to look at the words to see how they see the world. Translation needs an inner urgency that brings the very other to the closest proximity of the original (Müller 2012)2.

This reflection makes clear how close the art of translation is to Herta Müller. This is partly due to her attitude towards her own mother tongue, which she uses very consciously in her works, especially against the background that she grew up in the middle of a (German) language island, surrounded by a different majority language (Romanian). Her positive experiences with Romanian have led to an increased language awareness and a critical approach to her mother tongue (Lægreid 2013: 59-60). She has recognized that the structural and linguistic typology of German limits her perceptive power. With a new language like Romanian, which - in her perception - is particularly sensual, she can see things with different eyes and get to know new facets. Exactly this knowledge is also required for translation. It should take the "very other" into account, i.e. it must retain a certain foreignness in order to allow the recipient a new perspective. Walter Benjamin argues in this context that such an enrichment through a second language sets one's own language in motion through the foreign language, and thereby expands and deepens one's own language through the foreign language in a dialogical sense (after: Lægreid 2013: 59).

Translator competence in relation to professional translators is defined by translation studies as follows:

Translator competence is the macro-competence of professional translators consisting of several skills, dexterities, knowledge and even attitudes, which participates in the translation process seen as expert action and is divided into sub-competencies which are necessary for the success of macro-competence as a whole (Kelly 2002).

One of these sub-competencies, in addition to the aforementioned communicative and textual sub-competence in at least two languages and cultures and the thematic sub-competence, is the cultural sub-competence:

\footnotetext{
${ }^{2}$ All translations are provided by the author of this article, unless otherwise stated.
} 
Cultural sub-competencies means not only encyclopedic knowledge about countries in which the respective language is spoken, but also knowledge about values, myths, world views, beliefs and behaviors and how this is reflected in texts (Kelly 2002).

This definition, including the subdivision into sub-competencies, shows the changes that translation studies has undergone over the last 50-60 years. While at the beginning the language-centered view of translation dominated, nowadays translation studies are characterized by the so-called "cultural turn", which resulted, among other things, from the conclusion that linguistic translation studies were not appropriate for the needs of translation, because they overlook everything that goes beyond language analysis (Dąmbska-Prokop 2000: 15). Translation is therefore "always [also] a cultural transfer" (Reiß, Vermeer 1991: 4).

The cultural turn has also changed the role of the translator, who is more of a cultural ambassador than a pure language specialist. This change in roles is specifically reflected in various initiatives launched by translators to raise the awareness of other cultures through translations and additional promotions. This is particularly necessary when translating between or from smaller languages, for example between Polish and Czech or from Polish or Czech into German (just to mention a number of book presentations organized by the Deutsches PolenInstitut or the Tschechisches Zentrum).

When cultural competence is mentioned here, it is in the sense of culture as a "complex of social actions (art, religion, science, ethics), meanings and ideas" (Kupsch-Losereit 2002: 97). Only if the translator internalizes all these facets of the target language can he or she interpret symbols, signs and cultural codes. He is thus able to compare intellectual, aesthetic, socially relevant and economic values, moral and legal principles and patterns of behavior ${ }^{3}$ and can therefore make the right translational decisions when reproducing the original, "which take into account the culture-specific knowledge and experience requirements of source text and target text readers" (Kupsch-Losereit 2002: 97). Therefore, the cultural competence of the translator can also be seen as a "reflection of one's own cultural conditions and communication structures" (Kupsch-Losereit 2002: 97).

In this context, it should be examined to what extent it is advantageous for the translator to be a writer, as in the case of Radka Denemarková, who is both a translator and a writer. It can be assumed that thanks to her literary prerequisites she can also bring her ability to write creatively in another language to bear in translation and thus preserve Herta Müller's omnipresent imagery (which is also confirmed by Reinhard Kiesler's article Der Übersetzer als Schriftsteller published in 2000 and in Denemarková's statements themselves; see Kiesler 2000).

${ }^{3}$ These are cultural elements that can be found in the definition of Aleksander Kamiński (Kamiński 1974: 57). 
However, the ethical dimension of translator competence also plays a role here, i.e. the question of how much the translator is allowed to intervene in the original. The Polish translation scholar Anna Legeżyńska, for example, calls the translator "second author" (Legeżyńska 1997) and addresses in particular the fact that the translated text must ultimately function in exactly the same way as the original, or at least the illusion of it must be created (Legeżyńska 1997: 163).

Another important competence of the translator is his hermeneutic competence, which is the subject of an article by the outstanding Polish translation scholar Piotr de Bończa Bukowski (Bończa Bukowski 2012). If the translator is hermeneutically competent, he manages to "listen to the text and hear its meaning" (Bończa Bukowski 2012: 136). Despite the complex nature of understanding, i.e. a "holistic, selective, conscious and unconscious phenomenon oscillating between knowledge and intuition" (Bończa Bukowski 2012: 127), too little importance is usually attached to this first phase of the translation process. From a hermeneutic point of view, translation is "the generation of text comprehension" (Bończa Bukowski 2012: 128).

\subsection{Cultural experiences of two translators - biographical, artistic and cultural aspects}

In the search for an answer to the question of what cultural experience is, we could trace it back to cognitive routine (Langacker 1986: 16) in reference to cognitive linguistics: The more concepts a person is able to associate with their linguistic symbol, the more experience he has gained in reverse, the greater his cognitive routine. The cultural experience is reflected, as already mentioned, in "knowledge of values, myths, worldview, faith and behavior" (Kelly 2002) and is updated each time by the translational decisions made. The translator has cultural experience both in the source and target culture, to the extent that he is familiar with certain behavioral and thought patterns used in the original text as a result of previous contact with them.

It can be assumed that cultural experience goes hand in hand with linguistic experience, because language reflects the cognitive processes that occur during perception. When we perceive a phenomenon typical of a community, we get to know it through language, through the categories we know. So the greater our cognitive routine is, the easier it is to assign the respective phenomenon to a certain category. This thesis is confirmed, among other things, in the statements of the Austrian translation scholar Erich Prunč, because he notes that we can also consider language as a sign system in which the cultural experience of a community is reflected, handed down as such and thus also determines current patterns of thought and behavior (cf. Prunč 2001: 108).

In order to translate texts by an author such as Herta Müller, in which constant persecution and spying in a communist dictatorship is the main topic, the translator should be able to put himself in the position of the patterns of thought behind them. This is the only way he is able, for example, to correctly reproduce 
a biased and historical term such as "Polenfeldzug" ('Poland Campaign') (Müller 2009a: 53) in the target text.

\subsubsection{Radka Denemarková}

Radka Denemarková is a well-known writer, screenwriter, translator, teacher and dramaturg at the $\mathrm{Na}$ zábradli theatre in Prague. As part of her work as a dramaturg she has written a biography of film and theatre director Evald Schorm entitled Evald Schorm - Sám sobě nepritelem, in which she introduces the reader to his work in detail. Her best-known original work is a novel entitled Penize od Hitlera, which has been translated into 17 languages, including English and German (it was published under the titles Money from Hitler respectively Ein herrlicher Flecken Erde), and for which Radka Denemarková received the most important Czech literary prize, Magnesia Litera, in 2007. For the translation of the novel Atemschaukel (which was published in 2009 and can probably be regarded as a direct incentive to award to Herta Müller the Nobel Prize for Literature in the same year) into Czech, she received the same award in 2011 (published in Czech under the title Rozhoupaný dech; Müller 2010b).

To explore Radka Denemarková's cultural competence and cognitive routine, a look at her cultural background should be taken. Her professional and artistic career began with her studies of German and Czech language and literature at Charles University in Prague, where she received later her doctor's degree in 1997. Her dissertation dealt with the "Semiotic problem of dramatization. Intersemiotic translation using examples of Czech dramatizations of the 20th century. The problem of intertextuality' ${ }^{4}$. Early on, therefore, she was concerned about the connection between literary and translational activity, which is particularly evident in her anthropological approach to translation, as she analyses translation as the transition of a message from one system of signs to another (cf. Balcerzan 1998). After several scholarships, among others in Wiesbaden, 2008 in Berlin and 2010 in Graz, she became a research assistant at the Institute of Czech Literature at the Academy of Sciences of the Czech Republic and a lecturer and dramaturg at the $\mathrm{Na}$ zábradli theatre in Prague. Since 2004 she has been working as a writer, her most famous work being the already mentioned novel Penize od Hitlera.

Denemarková's views on Herta Müller as a public figure and writer can be used to draw conclusions for her artistic approach. She particularly appreciates Müller's fight against anti-Semitism, racism and all forms of totalitarianism (cf. Štráfeldová 2012), which she takes on despite various adversities, such as accusations of being a whistle-blower ${ }^{5}$.

Denemarková's reflection on Herta Müller's language shows her special artistic experience as a writer and translator at the same time. According to Denemarková, her language is "washed out" as if she regave words their meaning,

\footnotetext{
${ }^{4}$ In her monograph Sémiotická problematika dramatizaci (1997) Radka Denemarková discusses a total of 14 types of dramatization or dramatic meta-texts.

5 1984, in the December issue of the Banater Post, some authors suggested that Herta Müller had harmed the image of Germans living abroad. See Mahlberg 1994.
} 
words that often cheat us. She says she hears Müller's text, and this is not about individual words, but about a life experience (cf. Štráfeldová 2012). This very special empathy is also what Herta Müller herself appreciates about Denemarková (cf. ibid.).

Such sensitivity is furthermore the result of Denemarková's intensive examination of the literature and personality of the author to be translated - which she is obviously particularly called to do as a writer, because her reflections on Herta Müller's work are more of a literary essay than a report on her translation work. For example, she writes:

\begin{abstract}
She plants a forest of metaphors to convey a sense of what life in the concentration camps of the twentieth century was like. The result is a powerful, poetic testimony. The time of broken cuckoo clocks. I believe that before you start writing you have to leave the table and brush off the yellow crumbs of digested reality. Only then can you sit down again and begin to write about the inner reality. Herta Müller is not afraid of lyricism, tenderness, a child's point of view (can reality be used to scare children?), her brief chapters are like verses of a poem on a swing. But her prose never loses its brutally realistic edge, it is always brimming with bizarre characters. The deportations are never over. A return from the camp doesn't mean the camp is over (Denemarková 2014).
\end{abstract}

In the translation it becomes clear that Denemarková senses every nuance of her language. She manages to make Herta Müller's novels sound like originals in the Czech language, as if they were to be written in this way; consequently, at no point does it feel like "it sounds that way because it has been translated".

\title{
2.1.2. Katarzyna Leszczyńska
}

Katarzyna Leszczyńska is a respected translator - a fact that has been recognized by experts at the latest in 2015, when she was awarded the Karl Dedecius Prize. Her professional and artistic career began with her studies of German at the University of Warsaw and culminated in her doctorate at the European University Viadrina in Frankfurt/Oder (subject: Witches and Teutons. The Interest of National Socialism in the History of Witch Hunting). She is called the "Polish voice of Herta Müller", a nickname that shows that she has succeeded in creating "secondary texts" that appear like original Polish texts and at the same time take Herta Müller's linguistic, stylistic and cultural particularities into account.

An important and formative cultural experience is the Wisent-Reisen travel agency founded by her and her partner, which offers excursions in the footsteps of literature. There are different ways of mediating between cultures, translation is one of them. Katarzyna Leszczyńska enjoys her role as a mediator and a few years ago she wrote down her impressions from Vienna and Zurich in order to familiarize herself with these cities. Her work as a travel guide is an attempt to show tourists "her" Poland and Ukraine, e.g. the past of Poland's multicultural eastern border (Leszczyńska 2012). 
As a German teacher, she again inspired students to get to know German literature, music and German film. It thus proves the thesis of the translator as a cultural ambassador. According to her own statement, "the greatest challenge [...] is to immerse oneself in the world of the respective author and to make the cosmos created by him one's own. Translation is very «author-related»" (Fehlberg 2013), and not language-related, which applies in particular to Herta Müller's oeuvre.

Leszczyńska's approach to translation is characterized by the fact that, before embarking on the translation work, she tries to get to know the author in detail in order to fathom the origin of his creative decisions. Personal contact is therefore also important, because "when we feel sympathy with the author of texts that we like, it is a very interesting and enriching experience that indirectly also reveals something of the secret of his writing" (Leszczyńska 2012). However, concrete solutions for translation are the translator's sole responsibility: "[...] the author can help us out of some dead ends and misunderstandings, but he cannot help us with our own language" (ibid.). Rather, the reader holds the translator responsible for the linguistic form, while attributing the effort to the author to create a fictitious reality (Legeżyńska 1997: 42).

When translating the novel Atemschaukel, it was all the more important to delve into the origins of Müller's artistic decisions, as the Atemschaukel was conceived together with her then friend, the Romanian-German poet Oskar Pastior (even though he died before its publication). This circumstance had a significant influence on the translation, since the style and language had changed in comparison to Herta Müller's previous works: "I had to change for the book Atemschaukel. That was another language; one really felt Pastior in her language" (Fehlberg 2013).

Furthermore, with regard to Leszczyńska's cultural experience, the question arises as to the motivations that led her to deal with the highly sensitive activity of translation. The following quotation can give an important hint:

\section{[...] It was at the beginning of my studies, I discovered a collection of Kafka, Landarzt, and I was sure that these were the right stories for my friend. So I translated it to him immediately, clumsily, in this scenery. We experienced a fascinating adventure, and I think the enthusiasm compensated for the rather awkward translation (Leszczyńska 2012).}

This anecdote shows how important the personality of the translator is, because without enthusiasm and talent, only as a learned competence, it is impossible to become a good translator. It is also a practical illustration of how translation is the result of the need for interpersonal communication. Language exists as a means of communication, both individually and collectively, in so far as it corresponds to the cognitive needs and patterns of perception and imagination anchored in the respective culture.

Although Katarzyna Leszczyńska does not work as a writer and translator at the same time, she collects valuable artistic experience in other ways. The publication of Aglaja Veteranyi's Kto znajduje źle szukat ('Those who find it 
wrongly looked for'), initiated by her, consists of unpublished texts by this Romanian-Swiss author, texts about her and texts written in dialogue with her. This book exists only in Polish and was written out of Leszczyńska's fascination for the connection of theatre and literature in the work of this author. Leszczyńska's publication has - according to her - infected several actresses and directors with the work of Veteranyi and prompted them to grab other books by this author and use them in the theatre.

The relationship between the translator and his or her foreign language is also important for literary translation. It depends above all on how personal it is or whether it is connected with personal experiences. In this context, Leszczyńska says:

At the German Studies Institute, which I had chosen by chance, I was lucky enough to meet people like Karol Sauerland, Bożena Chołuj, Andrzej Kopacki, Anna Wołkowicz, who were for me a light in a dark tunnel of very "school-like" study: They shared their literary and philosophical fascination with us, they did not barricade themselves in the Germanistic backyard, but showed German literature in dialogue with other literatures, made us aware of the political power of literature and reflected on the art of translation. They made people read and think (Leszczyńska 2012).

At the same time, however, she also points out the following: Because the entire communication was in German right from the start, her own mother tongue was neglected. This addresses an important aspect of the translator's competencies, namely the "reflection on one's own cultural conditions and communication structures" (Kupsch-Losereit 2002: 97).

Thanks to her linguistic and cultural experience, Leszczyńska immediately recognizes characteristic features of Herta Müller's language:

Challenges are [...] for example the compound words so typical for the German language, which have very high symbolic significance for the author. Herta Müller uses words such as «Atemschaukel», «Herzschaufel», «Meldekraut» or «Hungerengel». These are special constructions and very poetic terms (Fehlberg 2013).

Herta Müller's language causes difficulties in translation, since compound words in the Polish language are rather a marginal phenomenon. The Polish linguist Kwiryna Handke rightly noted that a large number of the compound words present in the general Slavic vocabulary were created using foreign elements or models (Handke 1976: 5). In descriptive terms, this makes it difficult to maintain the imagery that results from the under-specification at the interface of the semantic fields of compound words. They can be regarded as a special case of metaphors having an exceptionally high status in Herta Müller's novels. It is impossible to specify a uniform specific semantics for all compound words, so they could be described as semantically underspecified: "The meaning of a compound word cannot be predicted until the relations between the individual 
components are known" (Perlitz 2014: 8). With regard to the Polish translation Leszczyńska notes:

I have to find nice and compact descriptions for many of these terms, because Polish does not know these compound words. Sometimes when it comes to emotions, she thinks or feels Romanian. Sometimes she uses words from the Banat-Swabian dialect. This is a challenge for translation. Especially with her first book it was difficult for me to find the right tone (Fehlberg 2013).

Before we look at some examples to show how Leszczyńska's cultural experience influences her translation strategy, it is worth taking a look at the criteria according to which she chooses the texts to be translated. She chooses

texts that affect the reader - be it by the horror, be it by the joke, by a special way of dealing with the word or by the provocation to think. They cannot be separated from what they have experienced and are politically important. This is literature that is very much rooted in German culture, but has also adopted something from other cultures. So a literature of the border (Fehlberg 2013).

Herta Müller's works also belong thematically and linguistically to the literature of the border. It is often referred to as Romanian-German literature - but Müller firmly rejects this. Her life companion, the writer Richard Wagner, also from Romania, even describes his literature and that of some of his companions such as Herta Müller as "anti-Romanian-German literature" (cf. Bozzi 2005: 19). Apart from Herta Müller's works, the texts translated by Leszczyńska include the novel Rahel Varnhagen. Lebensgeschichte einer deutschen Jüdin aus der Romantik ('Rahel Varnhagen. Life story of a German Jewish woman from the Romantic period') by Hannah Arendt and Angeklagt ('Accused') by Mariella Mehr, a Swiss woman from the Yenish minority. Both books confirm that Leszczyńska chooses "literature of the border". The first case deals with the story of a Jewish woman who belonged to a population group on the border of the inhabited country (Germany) and her Jewish nationality. In the case of the author Mariella Mehr, we are dealing with a Swiss woman who belongs to a minority (the Yenish) persecuted for a long time.

\subsubsection{Comparison of the translators' translation strategies}

Now that the two translators Radka Denemarková and Katarzyna Leszczyńska have been extensively portrayed, it is time to take a look at some concrete translation examples. This allows conclusions to be drawn about the influence of their cultural experience on the translation strategy.

Only if the translator takes on the role of mediator between cultures, "situationally appropriate translations" are possible (Legeżyńska 1997: 100). Both translators achieve this by creating functionally adequate associations in the secondary recipient through deviant idioms. For example, if one culture exposes 
the natural downward movement of the "stream" in a (modified) idiom (Wenns den Bach runtergeht, geht nicht nur der Bach runter; Müller 2009a: 21; 'When the stream goes down, not only the stream goes down'), other language images may be appropriate in the target language. According to the Czech translator, this is the logical consequence of tree felling (Když se kácí les, létaji třisky - 'If the forest is felled, the chips fly'; Müller 2010b: 20). At this point the Polish translator exposes the devil's deceitfulness (Jak wszystko diabli wezma, to nie diabli na tym ucierpia - 'If the devils take everything, it is not the devils who will suffer'; Müller 2010a: 18). However, the most important indicator here are the associations evoked in the secondary recipient. These could differ with the Czech reader, because the (unmodified) idiom used rather points to the logical consequence of an action, while the original idiom refers directly to the situation described in the novel (the prisoners must empty their bowels in an open field and something literally goes "down the stream"; cf. Müller 2009a: 21). The Polish, expanded idiom also alludes to something else: The person responsible for an incident is not necessarily the one who has to draw the consequences.

In the case of Radka Denemarková we can see a special feeling for the imagery of the original and a high sensitivity for any linguistic nuances. This can be seen, for example, in the translation of some representatives of fauna and flora in the novels Atemschaukel and Herztier. Denemarková usually preserves the original pictorial quality in such a way that it expands the encyclopedic names by their vernacular equivalents. An example is "Meldekraut" (Müller 2009a: 26) ('garden/red orache'). When she calls this spinach-like plant "lebeda lesklá bonzatá", she adds the term "bonzatá" to the biological name "lebeda lesklá" ("hoary orache'). This is a new creation derived from the pejorative noun "bonz". "Bonz" means "political, trade union, etc. activist with a dictatorial and proud attitude" (SSJC) and thus fits the connotation that resonates in the "Meldekraut".

The name "tuhýk devítismrtihlav", which is an extension of the encyclopedic name "t’uhýk" ('shrike') by the popular name "devítismrtihlav" (literally "nineheaded death'), comes from the world of fauna (in Herztier). Thus Denemarková manages to preserve the original connotation existing in the "Neuntöter" ('redbacked shrike'). This is mainly about the denotation "töten" ('to kill'), which would have been lost in translation without the addition "devítismrtihlav".

The addition of vernacular equivalents thus allows the translator to avoid interference with the original, does not change the semantics and at the same time introduces new and surprising elements for the Czech reader, thus maintaining functional equivalence.

In the case of "Meldekraut", Leszczyńska takes a different approach. "Meldekraut" is one of many neologisms so typical of Herta Müller's language (other examples are the titles of her novels like Atemschaukel, Herztier, the "Hungerengel" or the "Herzschaufel"). The encyclopedic name of the plant is "Melde" or "Gartenmelde". In Müller's linguistic world it can be regarded as a symbol of the omnipresent hunger in the camp. This plant looks like spinach, but does not taste like spinach and is only edible for a short period of the year. In order 
to preserve the play on words between "melde" in the sense of "melden" ("to denunciate; report') and "melde" as part of the plant name, the Polish translator has decided to clarify this play on words in the text itself, so that the Polish reader can understand the analogy between the components of this neologism:

Wiosna w obozie oznaczała dla nas gotowanie łobody. Jej niemiecka nazwa MELDEKRAUT jest mocna, ale nic nie znaczy. Dla nas, meldujących się na wysypisku, MELDE było słowem bez specjalnego wydźwięku, słowem, które zostawiało nas w spokoju. Nie brzmiało jak MELDUJ SIĘ, nie było rośliną apelową, tylko słowem na skraju drogi (Müller 2010a).

('The spring in the camp meant that we cooked garden orache. Its German name MELDEKRAUT is strong, but it doesn't mean anything. For us, who were registering at the landfill site, MELDE was a word without any special tone, a word that left us alone. It did not sound like MELDUJ SIE, it was not an appeal plant, but a word at the edge of the road')

This was the only way to preserve the imagery and analogy between "melden" and "Meldekraut". This translational decision testifies to the translator's cultural experience, who was aware that this play on words is indispensable, but at the same time Polish has no equivalents for "melden" and "Meldekraut", in each of which the denotation "melden" occurs. The Czech equivalent "lebeda lesklá bonzatá", on the other hand, also testifies to Radka Denemarková's cultural and literary maturity. It has managed not to change the semantics and at the same time, as in the original, introduced a new and surprising element.

Special cultural experience is required in the case of historical terms. Very often historical events are viewed from country to country or culture to culture from different perspectives, which is also reflected in the terminology. This plays a key role in any type of history report and is even capable of manipulating it (as a study on the different views on a historical topic in textbooks shows; cf. Wojdon 2014). Reinhart Koselleck notes in this context that "the dependency of individual events in the execution of their happening on their linguistic enabling [is clear]" (Koselleck 2006: 14).

When the original talk was of the "Polenfeldzug" ("Was am 1. September begonnen hatte, nannte mein Vater Blitzkrieg. Die Mutter sagte Polenfeldzug"; Müller 2009a: 53; 'What began on September 1, my father called Blitzkrieg. The mother said Poland Campaign'), it echoes the subjective glorification of it by the father of the main protagonist Leopold Auberg (cf. ibid.). This connotation is interpreted differently by both translators. In the Czech text we find the expression "vítězné válečné tažení do Polska" ('victorious campaign to Poland') (Müller 2010b: 49) and in the Polish version "kampania polska" ('Polish campaign') (Müller 2010a: 46).

Both translational decisions show how the terminology in this case reflects the world view. While "Polenfeldzug" suggests an act of war against Poland, the term "kampania polska" or "kampania wrześniowa" ('September campaign') is understood by the majority of Poles - as in the definition - as 'armed struggle in 
defense of Polish independence' (cf. Encyklopedia PWN). Thus, in one case there is talk of attack and in the other case of defense.

The Czech translation, on the other hand, more precisely reflects the author's intention, which with the mention of the "Polenfeldzug" alludes above all to the subjective, Nazi attitude of Leopold Auberg's father. It should be noted that "vítězné válečné tažení do Polska" is an evaluative and not the encyclopedic term used in history books.

As mentioned above, Herta Müller uses a large number of neologisms, which often have the structure of compound words and thus produce a high degree of imagery due to their unspecified nature. It is only through the use of compound words that she manages to compensate for the feeling of hopelessness and emptiness of the main protagonist. The resulting scope for interpretation means that the horrible is not expressed directly and is therefore more bearable. One of these compound words is "Herzblatt" (Müller 2009a: 82). Its translations into Polish and Czech sound as follows: "koncha-serce" (later also as "koncha") (Müller 2010a: 71) respectively "srdcovitý list" ("heart-shaped leaf') (Müller 2010b: 76). What immediately stands out is the structure that differs from the original in both cases. This can be explained, among other things, by the lack of idiomaticity of compound words in Slavic languages. The cultural experience is reflected in these examples in that the Czech translator consistently uses the element "srdcovitý" ('heart-shaped'), thus maintaining Herta Müller's intention to get unexpected meanings out of ordinary things, in this case the similarity of the shovel blade with a heart and the hope associated with this image. In the case of the Polish translation, this connotation is lost for two reasons: firstly, two-part expressions are unusual in Polish and disturb the flow of reading and secondly, the translator omits the element "serce" ('heart') in the further course (cf. Müller 2010a: 72).

Compared to Katarzyna Leszczyńska, it is striking that for Radka Denemarková translation is almost exclusively limited to Herta Müller. Although she is actually a writer, she has exceptionally agreed to translate novels. Her other translation work has so far been limited almost exclusively to Czech adaptations of some plays such as Elisabeth Hauptmann's, Bertolt Brecht's and Kurt Weill's HAPPY END (an exception is the translation of Pascal Mercier's Lea).

Both translators are united by the cultural proximity of Poland and the Czech Republic as two former socialist countries. Both grew up in the respective socialist system. In this respect they can empathize with Herta Müller and know what life under a communist dictatorship means: continuous fear of security services, denunciation, individual incapacitation, censorship.

However, the translation strategies of both translators differ in part, which is partly due to the fact that they both have different requirements for carrying out translation work. In the case of Radka Denemarková, the focus is on writing, which undoubtedly puts her at an advantage, as Herta Müller admits. This becomes clear when translating historically biased terms, but also when searching for functional equivalents in the target language, without the use of loan words 
(cf. the different translations of "Meldekraut"). Leszczyńska, on the other hand, pursues a high degree of accuracy and always tries to create functional equivalence. In some cases, however, this leads to the fact that some important associations or the flow of reading and idiomaticity are lost.

\section{Transculturalism of the author Herta Müller in view of the cultural experiences of the translators}

A translator is actually transcultural in his or her self-image, because he or she is constantly moving in the matter of two languages and sees beyond their boundaries, i.e. the translator does not view them in isolation but as different approaches to the same subject matter. Through constant contact with two languages and cultures, he has a broader worldview. This is an important prerequisite for correctly translating Herta Müller's texts into a foreign language. In this context, she speaks of the "eyes of language" (cf. Müller 2009b), which means that every newly learned language broadens one's horizon. The translator thus has a transcultural view, because he sees at the same time what is in two terms for the same denotation.

In Herta Müller's world, the cultural context can be seen as a potential carrier of foreignness. Consequently, multi- or transculturalism is the multiplication of foreignness. In Atemschaukel, multiculturalism is revealed in the micro-world of the "Nova Gorlovka" labor camp, where the carriers of foreignness are for example anthroponyms or third languages (Russian, Romanian, Banat dialect). In this micro-world the first-person narrator Leopold Auberg - whom we can connect with Herta Müller's former friend, Oscar Pastior, by means of epitexts (i.e. by means of reviews, interviews, debates, comments, etc.) - finds himself among people from different cultures. The camp is not a multicultural but a strongly transcultural environment, because the cultures of the prisoners are mixed under the influence of the situation in which they find themselves. All prisoners are united by hunger, fear and a common enemy: the labor camp guards.

In order to translate transcultural elements correctly, the translator must put himself in the position of a German-speaking recipient, as in the case of the sentence "Und die dritte war die Ration Chleb auf der russischen Waage" ("And the third was the ration of Chleb on the Russian scale') (Müller 2009a: 109). The expression "Chleb" ('bread') is clearly a borrowing from Russian and is a foreign element of great importance. It stands in contrast to the "Transylvanian one" that symbolizes the longing for everything that is connected with the home of the main protagonist. In this case, both translators have decided against introducing a functionally equivalent strangeness. While the Polish translator succumbed to the graphic similarity of the Polish "chleb" and Russian "Chleb" ("Trzeci to racjonowany chleb na rosyjskiej wadze"; Müller 2010a: 96) ("The third was the ration of Chleb on the Russian scale'), the Czech translator chooses a formulation that cleverly replaces the lexeme "Chleb" with "dietní příděl” ('dietary ration'): 
"A třetí byl dietní př́iděl ruské váhy" (Müller 2010b: 101). At the same time, it avoids the dilemma of the phonetic-graphic convergence of "Chleb" and enables the connotation within. On the other hand, it reveals more than intended to the reader and deprives him of the opportunity to experience the original strangeness for himself. An alternative would be the introduction of a phonetically different variant of "chleb" in the form of "chlieb" (Polish) respectively "chlěb" (Czech).

The secondary reader is also deprived of the opportunity to experience the original strangeness in other words coming mostly from Russian, like for example in "Jama" ('pit') (Müller 2009a: 125), for whose understanding the Germanspeaking reader must either have previous knowledge or use a dictionary. Both the Polish and Czech translations go beyond this nuance and succumb to the fact that both languages have the same lexeme, "jama" (Polish) (Müller 2010a: 112) and "jáma" (Czech) (Müller 2010b: 117).

Since both translators come from the Slavic-speaking world, one might think that maintaining transcultural nuances should not cause any difficulties. However, cultural proximity in particular can easily lead to simplifications or interference. This has become clear in the case of the lexemes "Chleb" and "Jama".

\section{Conclusion}

Both translators fulfill the maxim of translators as cultural ambassadors to a special degree. Katarzyna Leszczyńska does this mainly through her work in a travel agency, through close cooperation with Czarne publishing house, where all Herta Müller's Polish translations are published and where she makes suggestions for the translation of new works. Denemarková is a cultural ambassador in particular because she writes herself and then has her books translated into many other languages.

Without the much-discussed "cultural turn" in translation studies, however, these considerations would be irrelevant, since we could only have addressed linguistic aspects. The Czech translator in particular has internalized that translation is a cultural transfer and not a reproduction of individual words in the target language.

For both translators, the translation itself is author-related and not languagerelated. This is probably the reason why the Czech translator almost exclusively chooses Herta Müller as the author to translate.

Cultural experience manifests itself in inconspicuous linguistic elements: in the (not) literal translation of an idiom, in the compensation of structural differences (compound word) and in the use of historical terms. A successful translation often requires "second authorial" intervention, in order to preserve the original imagery. 


\section{References}

Balcerzan, Edward. 1998. Poetyka przekładu artystycznego. In ibidem (ed.), Literatura z literatury (Strategie tlumaczy), 17-31. Katowice: Wydawnictwo Naukowe Śląsk.

Bończa Bukowski, Piotr de. 2012. Hermeneutyczne kompetencje thumacza. In Maria Piotrowska et al. (ed.), Kompetencje thumacza. Kraków: Tertium.

Bozzi, Paola. 2005. Der fremde Blick: zum Werk Herta Müllers. Würzburg: Königshausen \& Neumann.

Dąmbska-Prokop, Urszula. 2000. Mała encyklopedia przekładoznawstwa. Częstochowa: Wydawnictwo Wyższej Szkoły Języków Obcych i Ekonomii Educator.

Denemarková, Radka. 2017. Radka Denemarková on translating Herta Müller. Transl. by Julia Sherwood. Asymptote. [Online]. Available from:

$<$ https://www.asymptotejournal.com/criticism/radka-denemarkova-on-translating-hertamuller/english/> [Accessed: $24^{\text {th }}$ August 2018]

Denemarková, Radka. 1997. Sémiotická problematika dramatizací. Doctoral thesis. Praha: Filozofická fakulta Univerzity Karlovy.

"Encyklopedia PWN" under the keyword "kampania wrześniowa". [Online]. Available from: https://encyklopedia.pwn.pl/haslo/kampania-wrzesniowa;3919678.html [Accessed: $26^{\text {th }}$ August 2018]

Fehlberg, Hauke. 2013. Literatur der Grenze: Vom Übersetzen deutschsprachiger Autoren ins Polnische. Polen.pl. [Online]. Available from: https://www.polen-pl.eu/literatur-der-grenze-vomuebersetzen-deutschsprachiger-autoren-ins-polnische/ [Accessed: 26 ${ }^{\text {th }}$ Augusr 2018]

Handke, Kwiryna. 1976. Budowa morfologiczna i funkcje compositów polskich. Wrocław: Zakład Narodowy im. Ossolińskich.

Kamiński, Aleksander. 1974. Funkcje pedagogiki społecznej. Warszawa: Państwowe Wydawnictwo Naukowe.

Kelly, Dorothy A. 2002. Un modelo de competencia traductora: bases para el diseño curricular. Puentes, 1, 9-20.

Kiesler, Reinhard. 2000: Der Übersetzer als Schriftsteller. In W. Dahmen and G. Holtus (eds.), Schreiben in einer anderen Sprache. Zur Internationalität romanischer Sprachen und Literaturen, 125-139. Romanistisches Kolloquium XIII. Tübingen: Gunter Narr Verlag.

Koselleck, Reinhart. 2006. Begriffsgeschichten - Studien zur Semantik und Pragmatik der politischen und sozialen Sprache. Frankfurt am Main: Suhrkamp Verlag.

Kupsch-Losereit, Sigrid. 2002: Die kulturelle Kompetenz des Translators. Lebende Sprachen, 47(3), 97-101. https://doi.org/10.1515/les.2002.47.3.97

Langacker, Ronald. 1986: An Introduction to Cognitive Grammar. Cognitive Science, 10(1), 1-40. https://doi.org/10.1207/s15516709 $\operatorname{cog} 1001 \_1$

Lægreid, Sissel. 2013. Sprachaugen und Wortdinge - Herta Müllers Poetik der Entgrenzung. In Sissel Lægreid, Helgard Mahrdt (eds.), Dichtung und Diktatur. Die Schriftstellerin Herta Müller. 55-79. Würzburg: Königshausen u. Neumann.

Legeżyńska, Anna. 1997. Tłumacz jako drugi autor - dziś. In Alina Nowicka-Jeżowa, Danuta Knysz-Tomaszewska (eds.), Przekład literacki. Teoria - historia - współczesność, 40-50. Warszawa: Państwowe Wydawnictwo Naukowe.

Leszczyńska, Katarzyna. 2012. Übersetzer im Gespräch - Katarzyna Leszczyńska. Goethe Institut. [Online]. Available from: https://www.goethe.de/ins/pl/de/kul/dos/ueb/ges/20554114.html [Accessed: 27th August 2018]

Mahlberg, Gerhard. 1994. Herta Müller: Herztier. New Literature. Review for Cross Connections 4. $103-108$.

Müller, Herta. 2009a. Atemschaukel. München: Carl Hanser Verlag.

Müller, Herta. 2009b. Die Augen der Sprache. In: Die Nacht ist aus Tinte gemacht: Herta Müller erzählt ihre Kindheit im Banat. Berlin: supposé; Hörbuch. 
Müller, Herta. 2010a. Huśtawka oddechu. Transl. by Katarzyna Leszczyńska. Wołowiec: Wydawnictwo Czarne.

Müller, Herta. 2010b. Rozhoupaný dech. Transl. by Radka Denemarková. Praha: Mladá fronta.

Müller, Herta. 2012. Zwischen den Sprachen. Asymptote. [Online]. Available from: https://www.asymptotejournal.com/nonfiction/herta-muller-the-space-betweenlanguages/german/ [Accessed: $27^{\text {th }}$ August 2018]

Perlitz, Laura. 2014. Konkurrenz zwischen Wortbildung und Syntax - historische Entwicklung von Benennung. Berlin: Humboldt-Universität zu Berlin, Philosophische Fakultät II, Institut für deutsche Sprache und Linguistik; bachelor thesis.

Prunč, Erich. 2001. Einführung in die Translationswissenschaft. Band 1: Orientierungsrahmen. Graz: Institut für Translationswissenschaft.

Reiß, Katharina; Vermeer, Hans J. 1991: Grundlegung einer allgemeinen Translationstheorie. Tübingen: Niemeyer.

$\mathrm{SSJC}=$ Slovník spisovného jazyka českého under the keyword „bonz“. [Online]. Available from: http://ssjc.ujc.cas.cz/search.php?hledej=Hledat\&heslo=bonz\&sti=EMPTY\&where=hesla\&hsubs tr $=$ no [Accessed: $20^{\text {th }}$ August 2018]

Štráfeldová, Milena. 2012. Hertha Müller mi potvrdila, že je třeba jít do rizika, říká její překladatelka Radka Denemarková. Radio Praha. [Online]. Available from:

https://www.radio.cz/cz/rubrika/udalosti/hertha-mueller-mi-potvrdila-ze-je-treba-jit-do-rizikarika-jeji-prekladatelka-radka-denemarkova [Accessed: 23 $3^{\text {rd }}$ August 2018]

Wojdon, Joanna. 2014. Kampania wrześniowa w polskich i zagranicznych podręcznikach szkolnych. Klio-Czasopismo Poświęcone Dziejom Polski i Powszechnym, 26(3), 117-139. https://doi.org/10.12775/KLIO.2013.035 